\title{
Analisis penerimaan pengguna aplikasi e-Kinerja dengan metode TRAM dan EUCS pada kepolisian
}

\section{Analysis of user acceptance of e-Kinerja applications with the TRAM and EUCS methods at the police}

\author{
Anthony Eko Hadisuwarno a, Rahadian Bisma ${ }^{b}$ \\ $a, b$ Sistem Informasi, Universitas Negeri Surabaya, Surabaya, Indonesia \\ email: ${ }^{a}$ anthonyhadisuwarno@mhs.unesa.ac.id,brahadianbisma@unesa.ac.id
}

\begin{tabular}{l}
\hline I N F O A R T I K E L \\
\hline Sejarah artikel: \\
Menerima 22 Juli 2020 \\
Revisi 13 Agustus 2020 \\
Diterima 22 Agustus 2020 \\
Online 21 Januari 2021 \\
\hline Kata kunci: \\
e-Kinerja \\
EUCS \\
penerimaan pengguna \\
PLS-SEM \\
TRAM
\end{tabular}

Keywords:

e-Kinerja

EUCS

PLS-SEM

TRAM

user acceptance

\section{Style APA dalam menyitasi} artikel ini:

Hadisuwarno, A. E., \&

Bisma, R. (2020). Analisis penerimaan pengguna aplikasi e-Kinerja dengan metode TRAM dan EUCS pada kepolisian. Teknologi: Jurnal Ilmiah Sistem Informasi, 10(2), 93-109.

\begin{abstract}
ABSTRAK
Penelitian ini bertujuan untuk mengetahui penerimaan pengguna dan faktorfaktor apa saja yang memepengaruhi penerimaan pengguna e-Kinerja. Model teori yang digunakan merupakan gabungan dari model teori adopsi teknologi TRAM (Technology Readiness Acceptance Model) dan EUCS (End User Computing Satisfaction). Variabel intention to use pada model TRAM digunakan sebagai penghubung dari dua model pada penelitian ini. Penelitian ini dilaksanakan di Polresta Sidoarjo. Pengumpulan data dilakukan dengan menggunakan kuesioner yang dibagikan secara langsung dengan teknik probability sampling yang melibatkan partisipasi 229 responden dari anggota Polresta Sidoarjo selaku pengguna aplikasi e-Kinerja. Teknis analisis data menggunakan PLS-SEM (Partial Least Square-Structural Equation Modelling). Hasil penelitian ini menyatakan bahwa terdapat tujuh hipotesis yang positif dan sepuluh negatif. Hasil temuan penelitian ini adalah niat pengguna berpengaruh positif dengan kepuasan pengguna dalam menggunakan aplikasi e-Kinerja, yang dapat diartikan bahwa pengguna merasa puas dan menerima aplikasi e-Kinerja sebagai sistem informasi yang dapat membantu pelaporan dan perhitungan kinerja setiap anggota Polresta Sidoarjo, Jawa Timur.
\end{abstract}

\section{ABSTRACT}

This study aims to determine user acceptance and what factors influence user acceptance of E-Kinerja. The theoretical model used is a combination of the theoretical model of technology adoption of TRAM (Technology Readiness Acceptance Model) and EUCS (End User Computing Satisfaction). For example, the intention to use variable in the TRAM (Technology Readiness Acceptance Model) model is used as a link between the two models in this study. This research was conducted in Sidoarjo Police by using a questionnaire that was distributed directly as a source of data with probability sampling technique involving the participation of 229 respondents from Sidoarjo Police as members of the e-Kinerja application. The data analysis technique used is PLS-SEM (Partial Least Square-Structural Equation Modeling). The results of this study state that there are seven positive and ten negative hypotheses. The findings of this study are the user's intention to positively influence user satisfaction in using the e-Kinerja application which can be interpreted that the user feels satisfied and accepts the e-Kinerja application as an information system that can help reporting and calculating the performance of each member of the Sidoarjo Police.

Teknologi: Jurnal IImiah Sistem Informasi dengan lisensi CC BY NC SA.

\section{Pendahuluan}

Masyarakat merasakan dampak sistem informasi saat ini yang dapat membantu dalam segala bidang. Tumbuhnya penggunaan teknologi informasi dan komunikasi (TIK) dalam layanan telah merevolusi Analisis penerimaan pengguna aplikasi e-Kinerja dengan metode TRAM dan ... $\quad$ http://doi.org/10.26594/teknologi.v10i2.2062 Teknologi: Jurnal IImiah Sistem Informasi dengan lisensi CC BY NC SA. 
interaksi antara penyedia layanan dan pengguna layanan. Lembaga-lembaga pelayanan publik sekarang berinovasi untuk memberikan pelayanan yang baik, cepat dan mudah. Di mana telah diatur oleh Peraturan Menteri Pendayagunaan Aparatur Negara dan Reformasi Birokrasi Republik Indonesia Nomor 53 tahun 2014 tentang Petunjuk Teknis Perjanjian Kinerja, Pelaporan Kinerja dan Tata Cara Reviu Atas Laporan Kinerja Instansi Pemerintahan, sehingga setiap lembaga berinovasi dalam memberikan pelayanan publik sebagai bentuk kinerja yang telah diatur. Salah satu contoh lembaga yang berinovasi adalah Polresta Sidoarjo yang merupakan polresta percontohan dengan banyak inovasi. Salah satu inovasi yang baru dari Polresta Sidoarjo adalah e-Kinerja yang berfungsi untuk memudahkan pelaporan kinerja setiap anggota polresta dalam bertugas dan menghitung tunjangan kinerja. Kesiapan individu dalam menggunakan sistem informasi menjadi salah satu yang penting dalam menentukan faktor-faktor yang mempengaruhi seseorang terhadap sistem informasi (Larasati, Widyawan, \& Santosa, 2017). Sehingga dalam implementasi suatu sistem informasi perlu mengetahui kesiapan pengguna dalam menggunakannya. Banyak penelitian yang membahas tentang kesiapan pengguna terhadap implementasi sistem informasi (Noprianto, 2016). Metode TRAM (Technology Readiness Acceptance Model) merupakan metode yang digunakan untuk menyelidiki niat pengguna dalam menggunakan suatu sistem (Kim \& Chiu, 2019). Namun, TRAM juga dapat digunakan untuk mengetahui penerimaan pengguna sesudah menggunakan sistem maupun kesiapan pengguna sebelum menggunakan sistem, dikarenakan TRAM sendiri merupakan teori model gabungan antara TR (Technology Readiness) dan TAM (Technology Acceptance Model) (BAŞGÖZE, 2015). Menurut Chen dan Lin (2018), TAM merupakan model yang berfokus pada faktor-faktor yang menentukan niat penggunaan ketika seseorang dihadapkan dengan teknologi baru. Sehingga dikombinasikan dengan model EUCS (End User Computing Satisfaction) dalam menilai suatu sistem yang telah dipakai sebagai tolak ukur penerimaan pengguna, dengan adanya kepuasan pemakai tersebut, maka akan timbul penerimaan (acceptance) pada sistem informasi yang dipergunakan dalam suatu organisasi (Yulianingsih, 2016).

Batasan dalam penelitian ini hanya meneliti di Polresta Sidoarjo, Jawa Timur dengan aplikasi eKinerja menggunakan model TRAM dan EUCS yang dikombinasikan untuk mengetahui faktor yang mempengaruhi penerimaan pengguna secara umum, tidak melihat tingkatan strata, umur dan jenis kelamin. Sesuai dengan tujuan penelitian ini untuk mengetahui faktor yang mempengaruhi penerimaan pengguna pada aplikasi e-Kinerja sebagai aplikasi internal dan mengetahui sejauh mana penerimaan pengguna terhadap aplikasi e-Kinerja. Hasil penelitian ini diharapkan dapat untuk memberikan masukan kepada Polresta terhadap aplikasi e-Kinerja.

\section{Tinjauan Pustaka dan Konseptual}

Tabel 1. Hasil penelitian terkait

\begin{tabular}{ll}
\hline \multicolumn{1}{c}{ Peneliti } & \multicolumn{1}{c}{ Hasil Penelitian } \\
\hline Kim \& Chiu (2019) & $\begin{array}{l}\text { Peneliti menemukan bahwa TR positif memengaruhi perceived ease of use (PEOU) dan perceived } \\
\text { usefulness (PU), sedangkan TR negatif memengaruhi perceived ease of use dan perceived } \\
\text { usefulness. } \\
\text { Peneliti memperluas model Technology Readiness Acceptance Model (TRAM) untuk } \\
\text { mempertimbangkan kesadaran individu sehingga meningkatkan kemampuan model untuk } \\
\text { memprediksikan niat dan sikap individu dalam mengakses aplikasi dietary dan fitness. }\end{array}$ \\
& $\begin{array}{l}\text { Dari penelitian ini menunjukkan bahwa model terintegrasi memberikan cara untuk } \\
\text { memahami faktor - faktor yang mempengaruhi niat untuk penggunaan aplikasi mobile apps. }\end{array}$ \\
Humbani \& Wiese (2018) & $\begin{array}{l}\text { Hasil dari penelitian ini menunjukan masing-masing variabel yaitu variabel isi, bentuk, } \\
\text { keakuratan, kemudahan serta ketepatan waktu berpengaruh secara positif dan signifikan }\end{array}$ \\
& terhadap kepuasan pengguna aplikasi. \\
Sari \& Syamsuddin (2017) & $\begin{array}{l}\text { Hasil penelitian berfokus pada kebutuhan untuk menerapkan sistem informasi yang memadai } \\
\text { untuk mempromosikan inovasi secara mendasar. Selain itu, perlu untuk memfasilitasi konteks } \\
\text { Escrig-Tena, Segarra- } \\
\text { Ciprés, García-Juan, \& } \\
\text { Beltrán-Martín (2018) }\end{array}$ \\
& partisipatif, dan keterbukaan terhadap lingkungan eksternal. \\
\hline
\end{tabular}

Dua dekade banyak penelitian tentang teori penerimaan pengguna yang dikembangkan oleh beberapa peneliti dengan model awal TRA (Theory of Reasoned Action) (Venkatesh, Morris, Davis, \& Davis, 2003). Salah satu model baru yang diteliti saat ini yaitu model TRAM dikembangkan oleh Lin, Shih, dan Sher (2007). TRAM sendiri merupakan model yang dikombinasikan antara model TRI (Technology Readiness Index) oleh Parasuraman (2000) dengan model TAM (Technology Acceptance Model) oleh Davis (1989). 
Model TRI merupakan model yang mengukur keyakinan individu terhadap teknologi umum, model TAM merupakan model yang mengukur kegunaan dan kemudahan penggunaan sistem (Lin, Shih, \& Sher, 2007). Berikut adalah penelitian tentang TRAM dan EUCS yang direplikasi dan dikembangkan disajikan pada Tabel 1 .

\subsection{TRAM (Technology Readiness Acceptance Model)}

TRAM (Technology Readiness Acceptance Model) merupakan model gabungan antara TRI (Technology Readiness Index) dan TAM (Technology Acceptance Model) pertama kali oleh (Lin, Shih, \& Sher, 2007) seperti yang disajikan pada Gambar 1. Dalam TR (Technnology Readiness) dibagi menjadi dua kelompok variable, antara lain optimism dan innovativeness sebagai variabel kontribusi, discomfort dan insecurity sebagai variabel penghambat. Empat variabel ini mempengaruhi dua variabel yang berasal dari TAM, yaitu perceived ease of use dan perceived usefulness yang mempengaruhi niat pengguna untuk menggunakan suatu teknologi. Penelitian BAŞGÖZE (2015) mencoba mengintegrasikan model TRI dan TAM setelah ada bukti, bahwa TRI tidak dapat mengukur kesiapan pengguna terhadap teknologi baru. Model TRI mengalami perkembangan menjadi TRI 2.0 dengan menambahkan dan merubah pengelompokan item pernyataan untuk penelitian TRI dan dapat digunakan dengan baik dengan model lain dalam penelitian (Martens, Roll, \& Elliott, 2017). Model TRI dan TAM merupakan model integrasi yang menjelaskan niat atau keinginan pengguna dalam menggunakan sistem informasi (Noprianto, 2016).

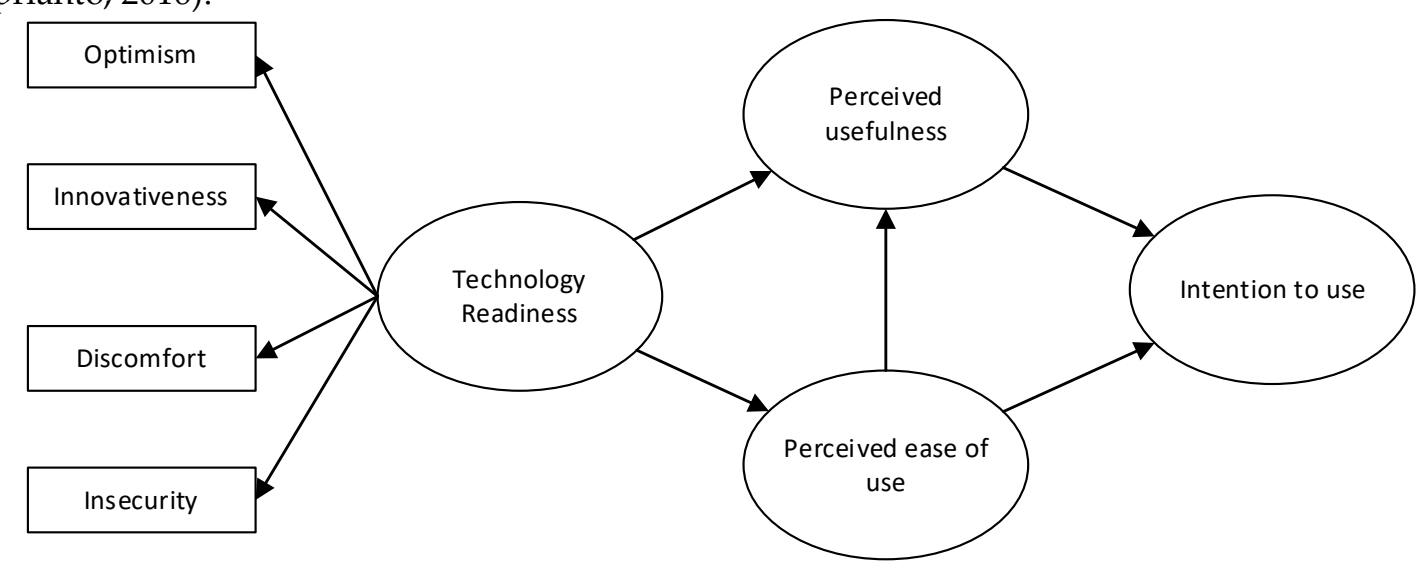

Gambar 1. Model TRAM (Lin, Shih, \& Sher, 2007)

\section{Optimism}

Pandangan positif terhadap teknologi dan pandangan terhadap manfaat teknologi dalam meningkatkan efisiensi dalam pekerjaan serta meningkatkan kinerja seseorang (Panday, Wibowo, \& Mardiah, 2019). Menurut Aisyah, Nugroho, \& Sagoro (2014), orang yang optimis paham bawah hal baik dan buruk akan silih berganti dalam hidup. Orang memilih menggunakan waktunya untuk aktif mencapai hasil yang positif yang memengaruhi hasil yang efektif dibandingkan dengan orang yang pesimis.

\section{Innovativeness}

Tingkat dalam melakukan eksperimen seseorang dalam menggunakan teknologi untuk menjadi yang paling depan dalam usaha mencoba teknologi baru (Panday, Wibowo, \& Mardiah, 2019). Menurut Aisyah, Nugroho, \& Sagoro (2014), tingkat individu yang ide-ide secara relatif lebih awal menggunakan dibanding dengan individu yang lainnya. Di mana orang yang inovatif memiliki kendala yang lebih kecil dalam menguasai teknologi baru. Orang yang mempunyai inovasi yang lebih tinggi sangat memahami manfaat teknologi baru tidak malu untuk memberitahu dengan orang sekitar.

\section{Discomfort}

Perasaan seseorang dalam menguasai teknologi dan rasa percaya diri yang minim dalam menggunakan suatu teknologi (Panday, Wibowo, \& Mardiah, 2019). Menurut Aisyah, Nugroho, \& Sagoro (2014), orang yang tidak nyaman dengan teknologi merasa membutuhkan bantuan dalam mengoperasikan teknologi baru dan cenderung untuk memakai teknologi yang sederhana, serta membuat orang pesimis dan tidak inovatif sehingga mempunyai pandangan bahwa teknologi baru sangat komplek dan menimbulkan pandangan bahwa teknologi tidak mudah untuk digunakan. 


\section{Insecurity}

Perasaan tidak percaya terhadap kemampuan teknologi dan keraguan terhadap kerja dari teknologi dalam menyelesaikan permasalahan (Panday, Wibowo, \& Mardiah, 2019). Menurut Aisyah, Nugroho, \& Sagoro (2014), orang yang mempunyai rasa ketidakamanan pada teknologi akan cenderung menghindari teknologi dan tidak akan berusaha untuk mencari tahu atau mencoba teknologi yang baru terkecuali dalam keadaan terpaksa. Orang yang mempunyai rasa ketidakamanan seperti ini menginginkan adanya jaminan terhadap rasa aman dan privasi sebelum menggunakan teknologi baru.

\section{Perceived usefulness}

Persepsi kegunaan dipengaruhi oleh persepsi kemudahan penggunaan. Kegunaan yang dirasakan didefinisikan sejauh mana seseorang percaya bahwa menggunakan suatu sistem akan meningkatkan pekerjaan. Suatu sistem yang sangat bermanfaat akan dirasakan pengguna dengan positif (Aditya \& Wardhana, 2016).

\section{Perceived ease of use}

Persepsi kemudahan dipengaruhi oleh persepsi sejauh mana seseorang percaya bahwa menggunakan suatu sistem akan bebas dari usaha yang sulit. Di mana kemudahan suatu sistem yang mudah dioperasikan oleh pengguna dari sistem-sistem yang ada (Aditya \& Wardhana, 2016).

\section{Intention to use}

Intention to use merupakan sikap positif dalam motivasi diri dalam menggunakan teknologi. Serta keinginan untuk memotivasi orang lain dalam menggunakan teknologi (Loanata \& Tileng, 2016).

\subsection{EUCS (End User Computing Satisfaction)}

End User Computing Satisfaction (EUCS) adalah model yang mengukur kepuasan pengguna terhadap sistem informasi. Dari pengalaman pengguna sistem dapat diukur berkaitan dengan kualitas saat menggunakan suatu system (Dalimunthe \& Ismiati, 2016). EUCS memiliki lima variabel antara lain Content (Isi), Accuracy (Akurasi), Format (Format), Ease of Use (Kemudahan) dan Timeliness (Ketepatan waktu) seperti pada Gambar 2. Lima variabel ini dapat mempengaruhi kepuasan pengguna, karena lima variabel ini merupakan komponen sistem yang dinilai pengguna sistem (Doll \& Torkzadeh, 1988). Berikut pengertian dari lima variabel dari EUCS:

\section{Content}

Content merupakan variabel untuk mengukur kepuasan pengguna dari isi suatu sistem (Damayanti, Mursityo, \& Herlambang, 2018). Isi dari suatu website biasanya berupa artikel atau fungsi yang dapat diakses oleh pengguna serta informasi yang ditampilkan oleh sistem. Di mana content dapat sebagai variabel untuk mengukur dari kepuasan pengguna dalam menampilkan informasi yang sesuai dengan kebutuhan pengguna (Sutanto, 2015). Contoh: Pada sistem E-Kinerja terdapat menu Home/Beranda pada content data pribadi pengguna, tetapi kurang lengkap karena tidak ada informasi tentang hasil yang telah tercapai dan persentase dari hasil pencapaian sehingga pengguna kurang puas dengan content.

\section{Accuracy}

Accuracy merupakan variabel untuk mengukur sisi keakuratan data yang ditampilkan oleh sistem (Damayanti, Mursityo, \& Herlambang, 2018). Keakuratan diukur dari data yang dimasukkan ke sistem dan minimnya kesalahan dalam proses pengolahan data (Sutanto, 2015). Contoh: Pada saat memasukkan kegiatan, di mana sistem dapat menerima angka maupun simbol yang tidak sengaja pengguna, kemudian sistem dapat memproses masukkan yang tidak sesuai dengan informasi yang pengguna harapkan.

\section{Format}

Format merupakan variabel yang mengukur kepuasan dari sisi tampilan dan estetika antarmuka sistem (Damayanti, Mursityo, \& Herlambang, 2018). Tampilan atau informasi yang dihasilkan sistem dapat menarik dan memudahkan pandangan pengguna dalam tata letak informasi yang ditampilkan (Sutanto, 2015). Contoh: Pada sistem e-Kinerja terdapat menu nama akun dan menu fitur dari e-Kinerja namun tata letak fitur nama akun yang biasanya terletak dibagian atas, tetapi pada sistem e-Kinerja terletak di bagian bawah, sehingga tidak memudahkan pengguna dalam mengetahui informasi dan kurang menarik dalam pandangan pengguna. 


\section{Ease of use}

Ease of use merupakan variabel yang mengukur kepuasan dari sisi kemudahan dalam penggunaan dan dipelajari serta dapat digunakan secara efektif (Damayanti, Mursityo, \& Herlambang, 2018). Kemudahan dalam penggunaan sistem seperti mencari data kegiatan, data hasil pencapaian dan lainlainya sesuai dengan kebutuhan pengguna (Sutanto, 2015). Contoh: Pada sistem e-Kinerja pengguna mudah dalam mencari data hasil pencapaian dengan adanya fitur menu hasil kinerja.

\section{Timeliness}

Timeliness merupakan variabel yang mengukur kepuasan dari ketepatan waktu aplikasi dalam menampilkan informasi yang dibutuhkan pengguna (Damayanti, Mursityo, \& Herlambang, 2018). Sistem yang real-time adalah sistem yang termasuk kategori tepat waktu, karena setiap masukkan yang dilakukan oleh pengguna akan langsung diproses oleh sistem dan dapat dilihat secara langsung oleh pengguna (Sutanto, 2015). Contoh: Pada sistem E-Kinerja pengguna menginputkan data kegiatan di mana sistem memproses data secara langsung dan menampilkan data kegiatan yang akan diverifikasi oleh atasan.

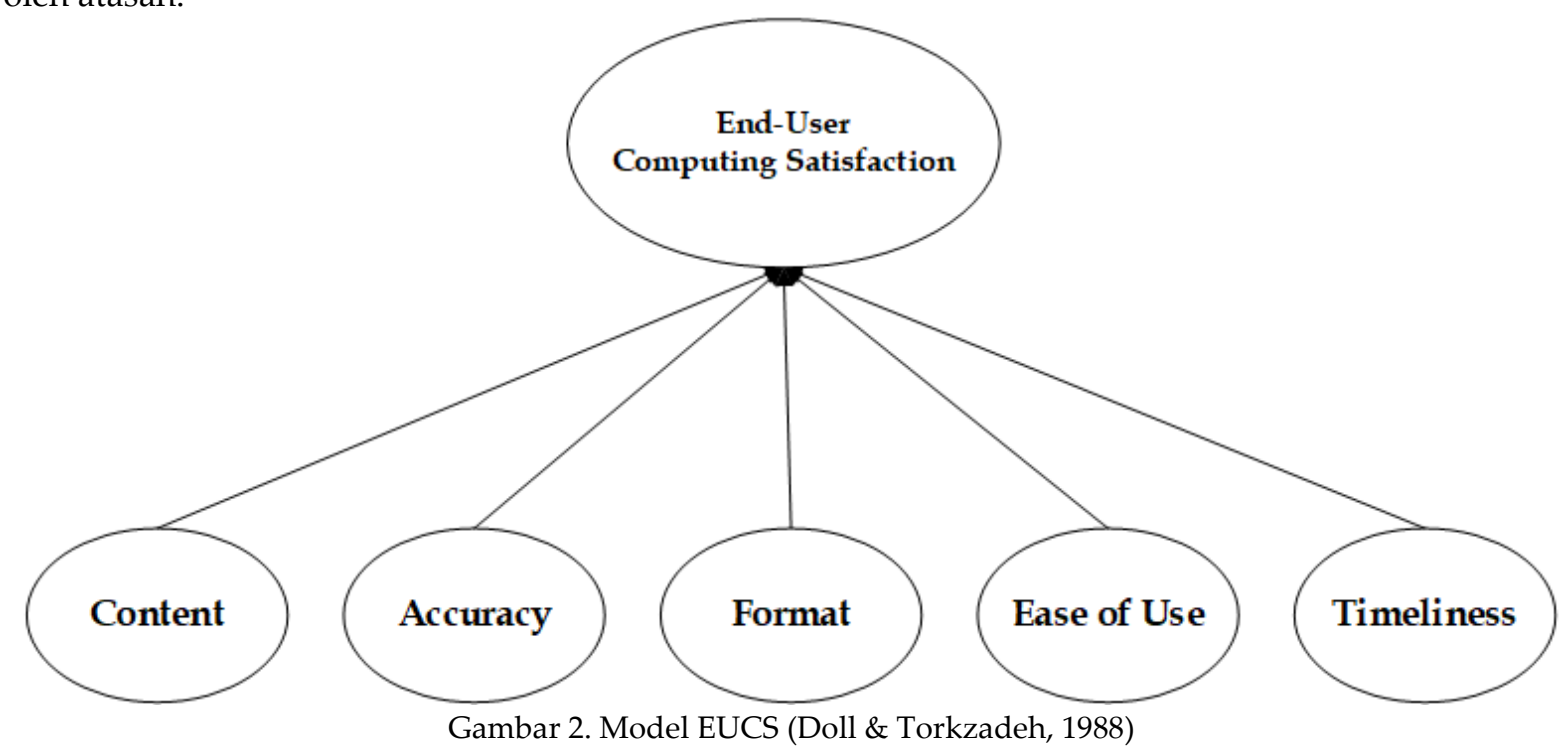

\section{Metode Penelitian}

Dalam penelitian ini memiliki alur penelitian yang sistematis dan berurutan dalam proses penelitian. Berfungsi untuk mengumpulkan data dan informasi serta melakukan peninjauan data dan informasi yang didapatkan untuk memudahkan dalam penelitian sebagai berikut:

a. Identifikasi objek

Tahapan ini merupakan tahap awal penelitian, kegiatan yang dilakukan adalah mengidentifikasi Polresta Sidoarjo sebagai objek penelitian.

b. Studi literatur

Kegiatan yang dapat dilakukan adalah mencari berbagai jurnal yang serupa dengan penelitian ini. Sehingga dapat mengetahui letak perbedaan antara penelitian ini dengan penelitian sebelumnya.

c. Rumusan masalah

Langkah selanjutnya setelah mengidentifikasi objek dan studi literatur, maka dilanjutkan untuk merumuskan masalah yang akan dijadikan tujuan penelitian. Kegiatan yang dilakukan adalah mengidentifikasi masalah melalui survei dan pengamatan pada pengguna.

d. Menentukan variabel

Tahapan ini digunakan untuk menentukan variabel yang berkaitan dengan tujuan penelitian. Variabel didapat melalui studi literatur pada teori yang telah diadopsi dalam penelitian untuk mengetahui faktor-faktor yang terkait dengan tujuan penelitian. Penelitian ini menggunakan dua teori dari model TRAM dan EUCS.

e. Pembuatan model dan hipotesis

Setelah menetapkan variabel penelitian, selanjutnya memetakan variabel ke dalam model konseptual. Model gabungan dua model teori yang saling terkait dari studi literatur yang dapat menghasilkan manfaat. 
f. Penyusunan instrumen

Menyusun instrumen diambil dari beberapa studi literatur dalam bentuk tabel untuk menentukan indikator-indikator yang ada. Sehingga dapat menghasilkan beberapa item pertanyaan yang mendasari variabel yang diajukan pada model konseptual dalam pembuatan kuesioner.

g. Penyusunan kuesioner

Setelah menyusun instrumen, menyusun kuesioner berdasarkan model konseptual dan hipotesis sebagai tujuan dari penelitian. Item pertanyaan yang digunakan kuesioner dibuat berdasarkan indikator-indikator dari tahapan penyusunan instrumen. Hasil yang didapatkan pada tahap ini adalah kuesioner.

h. Percobaan kuesioner

Tahap ini adalah penyebaran kuesioner pada sampel kecil sebanyak 24 responden yaitu anggota Polresta Sidoarjo, kemudian melakukan uji validitas dan reliabilitas menggunakan software SPSS. Pernyataan dari indikator dinyatakan valid apabila rhitung lebih besar dari rtabel. Sedangkan uji reliabilitas digunakan untuk mengukur suatu kuesioner yang merupakan indikator dari variabel. Suatu indikator dapat dikatakan reliabel jika memiliki nilai Cronbach's Alpha (CA) lebih besar 0,6 (Yamin \& Kurniawan, 2011).

i. Pengumpulan data

Dalam tahap ini, teknik pengumpulan data yang dilakukan oleh peneliti menggunakan kuesioner. Penyebaran kuesioner dilakukan secara langsung sebanyak 229 responden. Hasil yang didapat pada tahap ini adalah kuesioner yang telah diisi oleh seluruh responden anggota Polresta Sidoarjo.

j. Analisis data

Berdasarkan dari data kuesioner yang telah diisi oleh seluruh responden, maka akan dilakukan analisis data. Teknik yang digunakan untuk menganalisis data adalah "PLS-SEM" karena dalam penelitian ini menggunakan variabel dengan jumlah yang banyak dan tidak dapat diukur secara langsung. Analisis data dilakukan secara kuantitatif dengan mengolah data angka-angka menggunakan skala likert empat poin.

k. Pengujian hipotesis

Uji hipotesis bertujuan untuk menguji jawaban sementara, apakah benar terjadi pada sampel yang diteliti atau tidak. Apabila hipotesis benar dan terjadi berarti terbukti, dan apabila tidak benar berarti tidak terbukti. Pengujian terhadap hipotesis yang diajukan untuk membuktikan nilai setiap indikator yang ada pada TRAM dan EUCS.

1. Tahap akhir

Pada tahap akhir pada penelitian ini adalah membuat kesimpulan dan memberikan masukan dari hasil pengujian. Kesimpulan disusun berdasarkan hasil dari penelitian terhadap penerimaan pengguna dalam menggunakan teknologi e-Kinerja. Sedangkan masukan penelitian untuk memberikan saran perbaikan yang ditujukan kepada para pengembang sistem.

\subsection{Kerangka konseptual}

Pada Gambar 3 merupakan gabungan dari dua model yaitu model TRAM dan EUCS, variabel intention to use sebagai titik temu dengan variabel user satisfaction. Model TRAM adalah model gabungan TRI dan TAM. Model ini terdiri dari variabel intention to use, perceived usefulness dan perceived ease of use yang berasal dari model TAM. Sedangkan variabel optimism, innovativeness, discomfort dan insecurity berasal dari model TRI. EUCS terdiri dari lima variabel yang mempengaruhi user satisfaction yaitu content, format, accuracy, ease of use dan timeliness. Model konseptual menggambarkan niat pengguna dalam menggunakan e-Kinerja akan menghasilkan kepuasan untuk pengguna, berikut hipotesis:

H0. Intention to use berpengaruh positif terhadap user satisfaction pada e-Kinerja.

H1. Content berpengaruh positif terhadap user satisfaction pada e-Kinerja.

H2. Format berpengaruh positif terhadap user satisfaction pada e-Kinerja.

H3. Accuracy berpengaruh positif terhadap user satisfaction pada e-Kinerja.

H4. Ease of Use berpengaruh positif terhadap user satisfaction pada e-Kinerja.

H5. Timeliness berpengaruh positif terhadap user satisfaction pada e-Kinerja.

H6. Perceived usefulness berpengaruh positif terhadap intention to use pada e-Kinerja.

H7. Perceived ease of use berpengaruh positif terhadap intention to use pada e-Kinerja. 
H8. Perceived ease of use berpengaruh positif terhadap perceived usefulness pada e-Kinerja.

H9. Optimism berpengaruh positif terhadap perceived usefulness pada e-Kinerja.

H10. Optimism berpengaruh positif terhadap perceived ease of use pada e-Kinerja.

H11. Innovativeness berpengaruh positif terhadap perceived usefulness pada e-Kinerja.

H12. Innovativeness berpengaruh positif terhadap perceived ease of use pada e-Kinerja.

H13. Discomfort berpengaruh positif terhadap perceived usefulness pada e-Kinerja.

H14. Discomfort berpengaruh positif terhadap perceived ease of use pada e-Kinerja.

H15. Insecurity berpengaruh positif terhadap perceived usefulness pada e-Kinerja.

H16. Insecurity berpengaruh positif terhadap perceived ease of use pada e-Kinerja.

Gambaran dari konseptual dalam penelitian ini berawal dari user satisfaction dipengaruhi oleh intention to use di mana variabel ini juga dipengaruhi oleh variabel perceived usefulness dan perceived ease of use. Sedangkan variabel perceived usefulness dan perceived ease of use dipengaruhi oleh optimism, innovativeness, discomfort dan insecurity. Kemudian variabel user satisfaction dipengaruhi oleh intention to use, content, format, accuracy, ease of use dan timeliness. Penggabungan dua model ini berasal dari model teori DeLone \& McLean yang menyatakan bahwa, niat pengguna merupakan respons pengguna terhadap penggunaan sistem sehingga mempengaruhi kepuasan pengguna (Stefanovic, Marjanovic, Delić, Culibrk, \& Lalic, 2016).

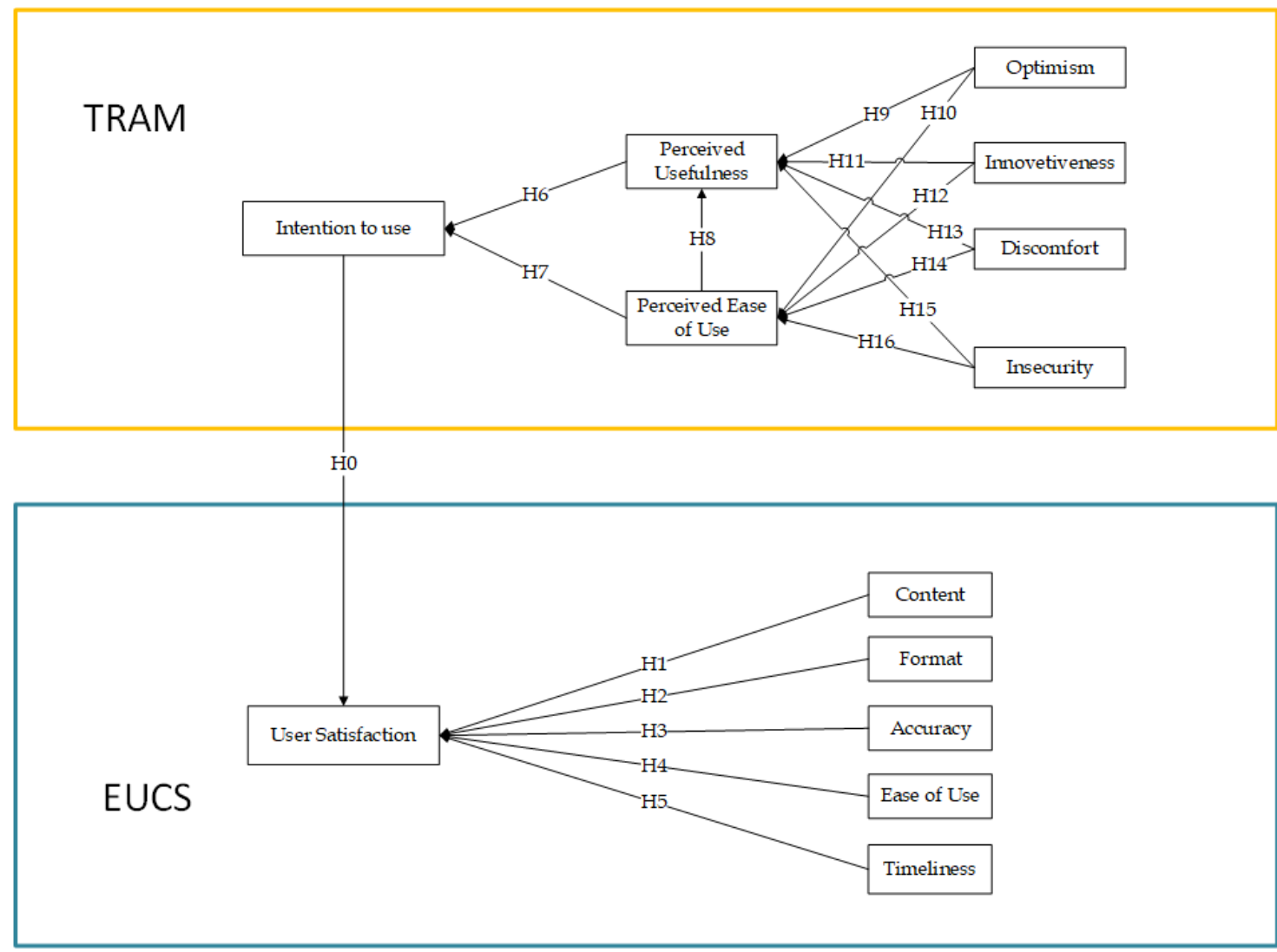

Gambar 3. Model konseptual

\subsection{Populasi dan sampel}

Dalam melaksanakan penelitian ini menggunakan sampel sebagai sumber data. Penelitian ini memakai teknik probability sampling, di mana kemungkinan atau peluang seseorang untuk terpilih menjadi anggota sampel tidak diketahui karena keputusan untuk memilih sampel dari total populasi tanpa melihat strata atau tingkatan dalam anggota populasi tergantung pribadi peneliti. Pada penelitian ini memakai sampel kurang lebih 229 pengguna e-Kinerja.

\subsection{Validitas dan reliabilitas}

Pada penelitian ini hasil uji validitas instrumen menggunakan bantuan software SPSS, dengan 12 item pernyataan yang tidak valid pada uji validitas dari total 72 item pernyataan, sehingga 12 item pernyataan tersebut tidak dapat digunakan pada tahap selanjutnya. Berdasarkan pada hasil uji 
reliabilitas instrumen menggunakan bantuan software SPSS, dari tiga belas variabel yang digunakan memiliki nilai CA di atas 0,6, sehingga tiga belas variabel tersebut reliabel dapat dilihat pada Tabel 2 .

Tabel 2. Hasil uji reliabilitas

\begin{tabular}{lcc}
\hline \multicolumn{1}{r}{ Variabel } & CA & Keterangan \\
\hline Content & 0,900 & Reliabel \\
Accuracy & 0,740 & Reliabel \\
Format & 0,750 & Reliabel \\
Ease of use & 0,873 & Reliabel \\
Timeliness & 0,878 & Reliabel \\
Optimism & 0,863 & Reliabel \\
Innovativeness & 0,676 & Reliabel \\
Discomfort & 0,715 & Reliabel \\
Insecurity & 0,792 & Reliabel \\
Perceived Usefulness & 0,824 & Reliabel \\
Perceived Ease of Use & 0,886 & Reliabel \\
Intention to Use & 0,866 & Reliabel \\
User Satisfaction & 0,712 & Reliabel \\
\hline
\end{tabular}

\section{4. $\quad$ Model pengukuran (outer model)}

Model pengukuran merupakan perhitungan antara variabel manifest atau indikator dengan variabel laten. Model pengukuran sendiri antara lain, validitas konvergen, t-statistik, Composite Reliability (CR), CA, AVE dan cross loading. Hasil model pengukuran dapat dilihat pada Tabel 3.

Pada Tabel 3, nilai outer loading semua indikator dinyatakan valid dalam mengukur variabel laten karena memiliki nilai $>0,5$, nilai t-statistik semua indikator berkorelasi secara signifikan terhadap variabel laten karena mempunyai nilai t-statistik $>1,97$, nilai CA semua variabel memiliki nilai $>0,6$ dan nilai CR semua variabel memiliki nilai $>0,7$ sehingga dapat dikatakan semua indikator valid dan reliabel dalam mengukur variabel laten. Nilai AVE merupakan merupakan batasan untuk membuktikan nilai validitas konvergen $>0,50$ semua indikator dapat membuktikan sesuai dengan validitas konvergen. Nilai cross loading dari masing-masing indikator mampu mengukur variabelnya sertas berkorelasi lebih tinggi dengan variabelnya sendiri daripada variabel lain.

\section{5. $\quad$ Model struktural (inner model)}

Pada pengujian model struktural (inner model) mengukur pola variabel antara variabel eksogen terhadap variabel endogen atau biasa disebut pengujian hipotesis. Hasil pengujian hipotesis dapat diterima jika berkorelasi positif dan berpengaruh signifikan dengan nilai t-statistik $>$ 1,96 (Yamin \& Kurniawan, 2011). Berikut hasil pengujian model struktural pada Tabel 4.

\subsection{Pengujian model gabungan}

Dalam memvalidasi model keseluruhan, diperlukan nilai goodness of fit (Gof). Goodness of Fit merupakan cara tunggal yang digunakan dalam memvalidasi gabungan antara model pengukuran dan model struktural. Ada tiga kategori nilai Gof adalah 0,1 (kecil), 0,25 (moderat), 0,36 (besar) sesuai dengan Persamaan 1,

GoF $=\sqrt{\overline{\overline{C o m}} \times \overline{R^{2}}}$

di mana nilai $\overline{\boldsymbol{C o m}}$ adalah rata-rata communalities. Nilai communalities diperoleh dari nilai AVE. Sedangkan untuk nilai $\overline{\boldsymbol{R}^{2}}$ diperoleh dari rata-rata nilai $\boldsymbol{R}^{2}$. Dari hasil perhitungan rata-rata communalities adalah 0,728 sedangkan nilai rata-rata $\boldsymbol{R}^{2}$ adalah 0,460 . Maka diperoleh hasil menggunakan Persamaan 1 dengan hasil sebagai berikut (Hasil keseluruhan disajikan pada Tabel 5).

GoF $=\sqrt{\overline{0,726} \times \overline{0,460}}=0,4(\mathrm{GoF}=$ besar $)$

\section{Hasil dan Pembahasan}

Pada penelitian Chen dan Lin (2018), variabel optimism berkontribusi positif terhadap kemudahan penggunaan dan kegunaan aplikasi diet dan kebugaran seperti yang dirasakan oleh individu. 
Penelitian (Hallikainen \& Laukkanen, 2016), menyatakan bahwa optimisme secara positif mempengaruhi persepsi kemudahan penggunaan dan persepsi manfaat layanan digital di antara pelanggan B2B. Namun optimis tidak berpengaruh signifikan pada persepsi kegunaan dalam menggunakan e-Kinerja yang merupakan aplikasi internal bukan aplikasi publik (OPT $\rightarrow$ PU) pada H9.

Tabel 3. Rangkuman hasil model pengukuran

\begin{tabular}{|c|c|c|}
\hline $\begin{array}{l}\mathbf{N} \\
\mathbf{0}\end{array}$ & $\begin{array}{c}\text { Model } \\
\text { Pengukuran } \\
\text { (Outer Model) }\end{array}$ & Nilai \\
\hline 1. & \multicolumn{2}{|c|}{ Validitas Konvergen } \\
\hline a. & Nilai Outer Loading & Indikator $\geq 0,5$ \\
\hline \multirow[t]{14}{*}{ b. } & \multicolumn{2}{|c|}{ Composite Reliability (CR) } \\
\hline & ACC & 0,956 \\
\hline & $\mathrm{CON}$ & 0,938 \\
\hline & DIS & 0,844 \\
\hline & EOU & 0,934 \\
\hline & FOR & 0,902 \\
\hline & INN & 0,807 \\
\hline & INS & 0,869 \\
\hline & ITU & 0,953 \\
\hline & OPT & 0,915 \\
\hline & PEOU & 0,956 \\
\hline & PU & 0,933 \\
\hline & TIM & 0,933 \\
\hline & US & 0,957 \\
\hline \multirow[t]{14}{*}{ c. } & \multicolumn{2}{|c|}{ Cronbach's Alpha (CA) } \\
\hline & $\mathrm{ACC}$ & 0,931 \\
\hline & $\mathrm{CON}$ & 0,912 \\
\hline & DIS & 0,758 \\
\hline & EOU & 0,915 \\
\hline & FOR & 0,837 \\
\hline & INN & 0,648 \\
\hline & INS & 0,801 \\
\hline & ITU & 0,925 \\
\hline & OPT & 0,888 \\
\hline & PEOU & 0,949 \\
\hline & PU & 0,920 \\
\hline & TIM & 0,894 \\
\hline & US & 0,911 \\
\hline \multirow[t]{14}{*}{ d. } & \multicolumn{2}{|c|}{ AVE } \\
\hline & ACC & 0,879 \\
\hline & $\mathrm{CON}$ & 0,790 \\
\hline & DIS & 0,577 \\
\hline & EOU & 0,702 \\
\hline & FOR & 0,755 \\
\hline & INN & 0,588 \\
\hline & INS & 0,625 \\
\hline & ITU & 0,871 \\
\hline & OPT & 0,643 \\
\hline & PEOU & 0,664 \\
\hline & PU & 0,635 \\
\hline & TIM & 0,824 \\
\hline & US & 0,918 \\
\hline \multirow[t]{2}{*}{2.} & \multicolumn{2}{|c|}{ Validitas Diskriminan } \\
\hline & Nilai Cross Loading & Baik \\
\hline
\end{tabular}

Faktor yang mempengaruhi optimis yaitu Flexibility dan Efficient. Flexibility merupakan kemampuan beradaptasi pengguna dalam menggunakan aplikasi e-Kinerja. Sedangkan Efficient dapat didefinisikan sejauh mana pengguna dapat mempersingkat waktu untuk melaporkan kegiatan dengan 
menggunakan e-Kinerja. Adaptasi pengguna e-Kinerja (Flexibility) tidak meningkatkan persepsi kegunaan. Hal ini dapat dicontohkan bahwa pengguna tidak mampu mengikuti dan memahami perubahan dalam pelaporan kinerja secara manual ke pelaporan terkomputerisasi menggunakan aplikasi e-Kinerja untuk mengatur aktivitas kerja setiap harinya. Pengguna juga merasa bahwa aplikasi e-Kinerja tidak menyesuaikan kebutuhan yang diinginkan pengguna. Sehingga membuat pengguna tidak yakin mampu menyesuaikan diri menggunakan e-Kinerja. Sedangkan Efficient juga tidak meningkatkan persepsi kegunaan karena pengguna sudah terbiasa melaporkan kegiatannya secara manual dengan menulis dibuku pelaporan yang sudah disediakan. Apalagi sekarang pengguna dituntut untuk menggunakan aplikasi E-Kinerja yang awam dan belum tentu semua pengguna memahami dan mengerti dengan cepat. Sehingga untuk menggunakan e-Kinerja setiap harinya, pengguna membutuhkan waktu yang lama untuk merasakan manfaat efisiensi dalam menggunakannya. Pada dasarnya, keyakinan pengguna bergantung pada manfaat yang dapat dirasakan ketika dengan cepat untuk menggunakan teknologi baik dari segi penyesuaian dan waktu penggunaan. Oleh karena itu, penelitian ini terbukti bahwa optimis tidak mempengaruhi persepsi kegunaan dalam menggunakan e-Kinerja.

Tabel 4. Hasil pengujian model struktural

\begin{tabular}{ccccc}
\hline Hipotesis & Variabel & $\begin{array}{c}\text { Original } \\
\text { Sample (O) }\end{array}$ & T Statistics & Keterangan \\
\hline H3 & ACC -> US & $-0,008$ & 0,096 & Ditolak \\
H1 & CON -> US & $-0,121$ & 0,887 & Ditolak \\
H14 & DIS -> PEOU & 0,063 & 0,702 & Ditolak \\
H13 & DIS -> PU & 0,007 & 0,102 & Ditolak \\
H4 & EOU -> US & 0,300 & 2,160 & Diterima \\
H2 & FOR -> US & 0,041 & 0,346 & Ditolak \\
H12 & INN -> PEOU & 0,356 & 4,380 & Diterima \\
H11 & INN -> PU & 0,117 & 1,649 & Ditolak \\
H16 & INS -> PEOU & 0,070 & 0,771 & Ditolak \\
H15 & INS -> PU & 0,134 & 2,234 & Diterima \\
H0 & ITU -> US & 0,590 & 7,568 & Diterima \\
H10 & OPT -> PEOU & 0,228 & 3,155 & Diterima \\
H9 & OPT -> PU & 0,074 & 1,197 & Ditolak \\
H7 & PEOU -> ITU & 0,250 & 1,863 & Ditolak \\
H3 & PEOU -> PU & 0,585 & 8,033 & Diterima \\
H1 & PU -> ITU & 0,444 & 3,775 & Diterima \\
H14 & TIM -> US & $-0,023$ & 0,192 & Ditolak \\
\hline
\end{tabular}

Tabel 5. Nilai communalities

\begin{tabular}{lc}
\hline \multicolumn{1}{c}{ Variabel } & Communalities \\
\hline Accuracy & 0,879 \\
Content & 0,790 \\
Discomfort & 0,577 \\
Ease of Use & 0,702 \\
Format & 0,755 \\
Innovativeness & 0,588 \\
Insecurity & 0,625 \\
Intention to Use & 0,871 \\
Optimism & 0,643 \\
Perceived Ease of Use & 0,664 \\
Perceived Usefulness & 0,635 \\
Timeliness & 0,824 \\
User Satisfaction & 0,918 \\
\hline
\end{tabular}

Menurut Chen dan Lin (2018), dampak inovasi lebih kuat daripada optimis terhadap persepsi kegunaan, karena inovasi individu dapat mendorong dalam mengunduh aplikasi kesehatan publik. Berbeda dengan e-Kinerja yang merupakan aplikasi internal, di mana inovasi tidak berpengaruh signifikan pada persepsi kegunaan dalam menggunakan e-Kinerja (INN $\rightarrow$ PU) pada H11. Faktor yang mempengaruhi inovasi yaitu tendency. Tendency didefinisikan sejauh mana pengguna memandang diri Analisis penerimaan pengguna aplikasi e-Kinerja dengan metode TRAM dan ... $\quad$ http://doi.org/10.26594/teknologi.v10i2.2062 Teknologi: Jurnal IImiah Sistem Informasi dengan lisensi CC BY NC SA. 
sendiri sebagai orang pertama dalam menggunakan e-Kinerja. Sikap Tendency tersebut tidak meningkatkan inovasi setiap pengguna. Hal ini dapat dicontohkan di lingkungan Polresta, bahwa setiap anggota dianjurkan untuk saling bekerjasama satu dengan yang lain dalam melaksanakan tugas, mereka tidak pernah mementingkan diri sendiri dalam melaksanakan tugas. Oleh karena itu, pada penelitian ini dapat disimpulkan bahwa inovasi tidak mempengaruhi pengguna terhadap persepsi kegunaan dalam menggunakan e-Kinerja karena pengguna telah terbiasa bekerjasama saling bahumembahu dalam melaksanakan tugas maka pengguna tidak dapat merasakan manfaat dari e-Kinerja secara individu.

Pada penelitian Lubis dan Mirzanti (2016), terdapat 2 hipotesis yang tidak signifikan antara lain inovasi terhadap persepsi kegunaan dan ketidaknyamanan terhadap persepsi kegunaan. Ketidaknyamanan tidak berpengaruh signifikan pada persepsi kegunaan dalam menggunakan eKinerja (DIS $\rightarrow$ PU) pada H13. Faktor yang mempengaruhi ketidaknyamanan yaitu technology dan feeling. Technology didefinisikan kemampuan pengguna menguasai suatu teknologi. Sedangkan feeling didefinisikan sejauh mana pengguna mempunyai rasa kuatir dan takut akan ketidakmampuan dalam menggunakan teknologi. Kemampuan setiap pengguna untuk menguasai teknologi tidak meningkatkan persepsi kegunaan e-Kinerja. Sedangkan feeling juga tidak meningkatkan persepsi kegunaan. Hal ini bisa dicontohkan bahwa di Polresta, e-Kinerja memiliki peran penting dalam pelaporan aktivitas harian anggota. Aplikasi ini mendorong semua kalangan untuk menggunakannya setiap hari sehingga menimbulkan kecemasan dan kekhawatiran tersendiri untuk anggota yang sudah beranjak ke usia lanjut. Ketidakmampuan daya ingat dan daya serap membuat mereka merasa malu karena tidak bisa menyelaraskan dengan kalangan muda. Oleh karena itu, ketidaknyamanan dalam menggunakan e-Kinerja tidak mempengaruhi pengguna untuk memahami dan memanfaatkan teknologi.

Pada penelitian Hallikainen dan Laukkane (2016) menyatakan bahwa inovasi, ketidaknyamanan dan ketidakamanan tidak berperan ketika pembuat keputusan pada layanan digital sektor B2B menilai kemudahan penggunaan dan kegunaan layanan digital. Sehingga mendukung hipotesis yaitu ketidaknyamanan tidak berpengaruh signifikan pada persepsi kemudahan dalam menggunakan EKinerja (DIS $\rightarrow$ PEOU) pada H14. Faktor yang mempengaruhi ketidaknyamanan yaitu technology dan feeling. Technology didefinisikan kemampuan pengguna menguasai suatu teknologi. Feeling didefinisikan sejauh mana pengguna mempunyai rasa kuatir dan takut akan ketidakmampuan dalam menggunakan teknologi. Sedangkan feeling juga tidak meningkatkan persepsi kemudahan penggunaan karena adanya perubahan prosedur pelaporan yang biasanya dilakukan secara manual dengan mencatat dibuku yang telah disediakan, sekarang harus online melalui e-Kinerja. Oleh karena itu ketidaknyamanan pengguna tidak mempengaruhi persepsi kemudahan dalam penggunaan e-Kinerja.

Pada penelitian Aisyah, Nugroho, dan Sagoro (2014) menjelaskan bahwa ketidakamanan (insecurity) memiliki pengaruhnegatif terhadap pandangan tentang teknologi, sehingga objek penelitian sangat mempengaruhi hasil pengujian pada adopsi teknologi yang tidak melibatkan unsur persaingan yang kuat. Ketidakamanan tidak berpengaruh signifikan pada persepsi kemudahan dalam menggunakan E-Kinerja (INS $\rightarrow$ PEOU) pada H16. Faktor yang mempengaruhi persepsi kemudahan yaitu Ability dan Harmful. Ability dapat didefinisikan ketidakmampuan seseorang dalam menggunakan teknologi. Harmful dapat didefinisikan pada kekuatiran akan konsekuensi bahaya dalam menggunakan teknologi tanpa adanya keamanan informasi yang mendukung pada suatu aplikasi. Ketidakmampuan pengguna e-Kinerja tidak meningkatkan persepsi kemudahan penggunaan. Hal ini dicontohkan bahwa setiap pengguna e-Kinerja mempunyai keahlian yang berbeda dalam bidang teknologi. Selain itu juga khawatir ketika informasi privasi pengguna yang telah tersimpan dalam eKinerja dapat disalahgunakan. Apalagi e-Kinerja masih berbasis website memiliki keamanan sistem yang rentan akan diretas oknum yang tidak bertanggung jawab. Sehingga banyak pengguna menjadi takut untuk menggunakan e-Kinerja. Oleh karena itu membuat pandangan pengguna dari sisi ketidakamanan ini tidak mempengaruhi persepsi kemudahan menggunakan e-Kinerja.

Pada penelitian Kim dan Chiu (2019), menyatakan bahwa persepsi kegunaan lebih kuat daripada persepsi kemudahan terhadap niat penggunaan. Persepsi kemudahan tidak berpengaruh signifikan pada niat pengguna dalam menggunakan e-Kinerja (PEOU $\rightarrow$ ITU) pada H7. Faktor yang mempengaruhi persepsi kemudahan yaitu Ease of learning, Easy to use, Ease of Remembering dan Flexible. 

didefinisikan tingkat kemudahan sistem untuk dipergunakan dalam sehari-hari, Ease of Remembering dapat artikan sebagai kemudahan dalam menggunakan sistem untuk diingat pada saat dipergunakan dan tidak membuat pengguna bingung dan Flexible didefinisikan sebagai mana sistem dapat dipergunakan dengan mudah pada lingkungan kerja.

Kemudahan dalam mempelajari e-Kinerja tidak meningkatkan niat pengguna. Hal ini dapat dicontohkan bahwa Polresta mengembangkan e-Kinerja bukan hanya untuk digunakan anggota muda saja tetapi anggota usia lanjut juga. Daya ingat dan daya serap anggota lanjut usia sangat mempengaruhi proses belajar dalam memahami e-Kinerja, sehingga menyebabkan perbedaan kecepatan pengguna dalam merespon dan menanggapi penggunaan E-Kinerja.

Kemudahan e-Kinerja untuk digunakan setiap harinya tidak meningkatkan niat pengguna. Hal ini juga dapat dicontohkan bahwa pengguna merasa bahwa informasi yang mereka butuhkan kurang lengkap dan jelas. Selain itu juga tampilan antar muka belum user friendly sesuai kebutuhan pengguna. Sehingga pengguna terkadang masih bertanya ke pengguna lain terkait cara kerja atapun fungsi fitur yang telah tersedia pada E-Kinerja untuk kesehariannya.

Ease of Remembering tidak meningkatkan niat pengguna karena sebagian besar pengguna masih kebingungan dengan beberapa kegunaan fungsi tombol fitur yang ada di E-Kinerja. Salah satunya bagian fitur pencarian yang ditampilkan oleh aplikasi e-Kinerja tanpa memberi contoh masukkan pada pengguna, menyebabakan user kurang paham dan mengerti. Sehingga perlu adanya pengembangan ulang aplikasi pada e-Kinerja terkait detail tombol fitur serta penambahan informasi sesuai kebutuhan pengguna. Selain itu juga perlu adanya SOP (Standard Operasional Procedure) penggunaan e-Kinerja bisa berbentuk diagram flow, video maupun gambar.

Sedangkan flexibel tidak meningkatkan niat pengguna karena kurangnya akses komputer pada e-Kinerja yang hanya terdapat di bagian tertentu. Selain itu penggunaan e-Kinerja melalui website di smartphone masih menyulitkan pengguna akan kendala sinyal dalam waktu akses maupun kendala smartphone yang tidak layak pakai. Sehingga kemudahan dalam penggunaan e-Kinerja di lingkungan kerja kurang maksimal. Oleh karena itu persepsi kemudahan penggunaan e-Kinerja tidak mempengaruhi niat pengguna dalam lingkungan kerja.

Pada penelitian Sari dan Syamsuddin (2017), menyatakan bahwa hasil penelitian menunjukan bahwa konten mempengaruhi kepuasan pengguna, di mana semakin besar persepsi positif pengguna aplikasi terhadap konten aplikasi ini, semakin besar pula persepsi kepuasan pengguna, namun hasil penelitian ini menunjukan konten tidak berpengaruh signifikan pada kepuasan pengguna dalam menggunakan e-Kinerja (CON $\rightarrow$ US) pada H1. Faktor yang mempengaruhi konten yaitu information. Information didefinisikan seberapa spesifik atau lengkapnya informasi yang ditampilkan oleh sistem. Informasi tidak meningkatkan kepuasan pengguna karena konten atau infomasi yang ditampilkan pada e-Kinerja kurang terperinci dan jelas. Contohnya pada halaman dashboard hanya memunculkan isi dari identitas pengguna saja. Pada dashboard bisa dikembangkan lagi untuk memuat informasi tentang tunjangan kinerja yang telah dicapai ataupun belum tercapai dan informasi perbandingan total durasi kinerja dalam kurun waktu dua hari yang lalu. Sehingga pengguna merasa terbantu dengan adanya informasi lebih spesifik dan jelas pada dashboard website e-Kinerja. Oleh sebab itu konten tidak mempengaruhi terhadap kepuasan pengguna pada e-Kinerja.

Pada penelitian Suzanto dan Sidharta (2015), menyatakan variabel accuracy tidak berpengaruh signifikan terhadap sikap mahasiswa karena penyajian informasi akademik tidak dilakukan secara feedback, sehingga tidak tahu sejauh mana informasi yang diberikan sesuai dengan yang ditetapkan. Akurasi tidak berpengaruh signifikan pada kepuasan pengguna dalam menggunakan e-Kinerja (ACC $\rightarrow$ US) pada H3. Faktor yang mempengaruhi akurasi yaitu Accuracy system. Accuracy system didefinisikan sisi keakuratan data yang di tampilkan oleh sistem. Keakuratan sistem tidak meningkatkan kepuasan pengguna. Hal ini dikarenakan sistem e-Kinerja tidak memiliki keakuratan terhadap informasi yang diberikan. Pengguna merasa informasi yang diberikan masih kurang jelas, contoh pada bagian fitur pencarian yang ditampilkan oleh aplikasi e-Kinerja tanpa memberi contoh masukkan, sehingga pengguna kurang mengerti fitur pencarian dalam format apa, karena banyak fungsi fitur pencarian. Sehingga kurang akurat dan dapat membingungkan pengguna jika pengguna tersebut masih awam terhadap e-Kinerja. Selain itu juga, data angka pada e-Kinerja masih ada yang 
tidak memiliki satuan sehingga pembacaan angka didalam e-Kinerja kurang detail. Oleh sebab itu akurasi tidak mempengaruhi kepuasan pengguna terhadap e-Kinerja.

Hasil penelitian Suzanto dan Sidharta (2015), menyatakan bahwa format signifikan berpengaruh terhadap kepuasan pengguna karena telah disajikan dalam bentuk informatif dan lugas. Namun, format tidak berpengaruh signifikan pada kepuasan pengguna dalam menggunakan e-Kinerja (FOR $\rightarrow$ US) pada H2. Faktor yang mempengaruhi format yaitu Aesthetics. Aesthetics didefinisikan sisi tampilan dan estetika antarmuka sistem yang dapat menarik dan memudahkan pengguna untuk membaca setiap informasi. Estetika antarmuka pengguna tidak meningkatkan kepuasan pengguna e-Kinerja. Hal ini dapat dicontohkan bahwa e-Kinerja memiliki format tampilan yang kurang menarik dikarenakan banyak ukuran tampilannya tidak sesuai standar ukuran semestinya. Seperti halnya fitur pencarian berdasarkan tanggal yang sangat panjang mungkin bisa disesuaikan ukuran standarnya sehingga bisa menarik pengguna dan tidak memakan banyak tempat pada tampilan halaman website. Oleh karena itu, format yang ada saat ini tidak mempengaruhi terhadap kepuasan pengguna e-Kinerja.

Pada penelitian Suzanto dan Sidharta (2015), menunjukan hasil ketepatan waktu yang signifikan, namun penelitian ini ketepatan waktu tidak berpengaruh signifikan pada kepuasan pengguna dalam menggunakan e-Kinerja (TIM $\rightarrow$ US) pada H5. Faktor yang mempengaruhi ketepatan waktu yaitu time. Time didefinisikan ketepatan sistem dalam memproses dan menampilkan data yang sesuai. Ketepatan sistem tidak meningkatkan kepuasan pengguna karena aplikasi e-Kinerja pada saat memuat halaman utama pada website masih kurang cepat ini membuat pengguna e-Kinerja yang diluar lingkungan Polresta kurang merasakan manfaat dari aplikasi tersebut. Sehingga kualitas kecepatan loading website yang kurang cepat, akan menunjukkan kepada pengguna berapa lama waktu menunggu untuk bisa mengakses tampilan aplikasi e-Kinerja. Oleh karena itu, ketepatan waktu aplikasi e-Kinerja tidak mempengaruhi pada kepuasan pengguna.

Hasil yang sama dengan penelitian Suzanto \& Sidharta (2015) dan Sari \& Syamsuddin (2017), di mana kemudahan berpengaruh signifikan pada kepuasan pengguna dalam menggunakan E-Kinerja $($ EOU $\rightarrow$ US) pada H4. Faktor yang mempengaruhi kemudahan yaitu Efficient dan Ease of use. Efficient dapat didefiniskan sejauh mana pengguna merasakan efisien dalam menggunakan aplikasi E-Kinerja yang dapat mempersingkat waktu absensi dan pelaporan kegiatan. Ease of use didefinisikan sejauh mana sistem mudah dalam penggunaan di setiap harinya, di mana pengguna merasa efisien dalam meggunakan aplikasi kemudian muncul perasaan mudah dalam menggunakan aplikasi E-Kinerja. Dengan banyaknya kegiatan pada Polresta Sidoarjo, pengguna aplikasi E-Kinerja sangat terbantu dalam pelaporan kegiatan yang sudah diselesaikan dan membantu instansi dalam mengawasi serta mengontrol kegiatan anggota dalam bertugas.

Pada penelitian Lubis dan Mirzanti (2016), menyatakan bahwa terdapat 2 hipotesis yang tidak signifikan antara lain inovasi terhadap persepsi kegunaan dan ketidaknyamanan terhadap persepsi kegunaan. Begitu juga dengan penelitian Martens, Roll, dan Elliott (2017), di mana menunjukan bahwa inovasi juga tidak signifikan terhadap persepsi kegunaan. Inovasi (Innovativeness) berpengaruh signifikan terhadap persepsi kegunaan (Perceived Usefulness) aplikasi E-Kinerja (INN $\rightarrow$ PU) pada H11. Faktor yang mempengaruhi inovasi antara lain tendency. Tendency didefinisikan sejauh mana orang mempunyai sifat atau sikap kecenderungan untuk menjadi pelopor pengguna teknologi. Dengan semangat menjadi pelopor ini Polresta Sidoarjo menjadi Polresta percontohan dari 4 (empat) di Jawa Timur yang terus berinovasi dalam memberikan pelayanan pada masyarakat dan birokrasi yang bersih dari segala bentuk KKN (Korupsi Kolusi dan Nepotisme). Peningkatan status dari Polres menjadi Polresta, Polresta Sidoarjo berinovasi terus dengan meningkatkan pelayanan baik dari sisi luar maupun dalam birokrasi. Semangat inovasi ini tertanam dalam setiap pengguna aplikasi e-Kinerja, karena aplikasi e-Kinerja merupakan aplikasi internal dalam pelaporan kegiatan yang sudah dikerjakan sehingga mempermudah dalam pemantauan setiap kegiatan yang telah diselesaikan pada setiap anggota Polresta Sidoarjo. Polresta Sidoarjo telah bekerja sama dengan KEMENPAN-RB (Kementrian Pendayagunuaan Aparatur Negara dan Reformasi Birokrasi), dalam kemajuan yang telah dicapai oleh Polresta Sidoarjo dengan memberi tunjangan kinerja kepada pengguna aplikasi e-Kinerja sesuai dengan kinerja yang telah dicapai. Sehingga pengguna aplikasi ini merasakan kegunaan teknologi yang dapat mempercepat kinerja. 
Ketidakamanan (Insecurity) berpengaruh signifikan terhadap persepsi kegunaan (Perceived Usefulness) pada aplikasi e-Kinerja (INS $\rightarrow$ PU) pada H15. Faktor yang mempengaruhi ketidakamanan yaitu ability dan harmful. Ability dapat didefinisikan dengan ketidakmampuan seseorang dalam menggunakan teknologi dan harmful dapat didefinisikan pada kekuatiran akan konsekuensi bahaya dalam menggunakan teknologi tanpa adanya keamanan informasi yang mendukung pada suatu aplikasi. Ability atau ketidakmapuan seseorang dalam menggunakan teknologi ini dapat diartikan saat seseorang mendapatkan tugas mendadak untuk keluar kota namun seseorang ini tidak dapat memakai apllikasi e-Kinerja dikarenakan aplikasi e-Kinerja yang masih berbasis web dan aplikasi internal yang hanya bisa diakses oleh anggota Polresta Sidoarjo, serta web yang dapat diakses untuk di luar lingkungan Polresta Sidoarjo. Namun, seringkali pengguna merasa kesusahan dalam mengakses eKinerja yang berbasis website dikarenakan ketiadaan waktu untuk membuka website, karenakan waktu penyelesaian tugas dan melaporkan kegiatan apa yang sedang dikerjakan. Serta dalam penggunaan aplikasi website yang kurang aman untuk aplikasi e-Kinerja, karena banyak kasus peretasan website pada beberapa tahun ini. Pengguna merasa kurang aman akan penggunaan website ini, dalam aplikasi yang berbasis website ini banyak informasi tentang pengguna e-Kinerja sehingga perlu pengamanan yang baik untuk menciptakan rasa percaya kepada pengguna e-Kinerja. Sehingga mempengaruhi persepsi kegunaan untuk pengguna e-Kinerja, hasil ini berbeda dengan penelitian sebelumnya Martens, Roll, dan Elliott (2017), di mana ketidakamanan tidak signifikan dengan persepsi kegunaan.

Niat pengguna (Intention to Use) berpengaruh signifikan pada kepuasan pengguna (User Satisfaction) E-Kinerja (ITU $\rightarrow$ US) pada H0. Faktor yang mempengaruhi niat pengguna terhadap kepuasan pengguna adalah Ability, dapat didefinisikan pengguna mempunyai kemampuan dalam menggunakan aplikasi dan pemahaman dalam menggunakan aplikasi e-Kinerja. Dalam implementasi aplikasi Polresta Sidoarjo membentuk PIC (Person in Charge) pada setiap bagian yang mempunyai tanggung jawab untuk membantu rekannya dalam pemahaman tata cara menggunakan aplikasi eKinerja. Teknik yang dilakukan Polresta Sidoarjo sangat efektif untuk menerapkan aplikasi e-Kinerja kepada anggota. Hal ini juga dipengaruhi oleh karena niat pengguna dalam menggunakan teknologi yang telah menggunakan teknologi lainnya selain aplikasi e-Kinerja sehingga membuat pengguna merasa puas akan keberhasilan dalam menggunakan e-Kinerja.

Optimis (Optimism) berpengaruh signifikan terhadap persepsi kemudahan (Perceived Ease of Use) pada e-Kinerja (OPT $\rightarrow$ PEOU) pada H10. Faktor yang mempengaruhi pada optimis adalah flexibility dan efficiency, flexibility didefinisikan sejauh mana pandangan orang dalam menyesuaikan diri untuk menggunakan aplikasi e-Kinerja. Efficiency merupakan karakteristik seseorang yang memiliki kepercayaan diri dalam menggunakan e-Kinerja, bahwa e-Kinerja dapat menghemat waktu pengguna pada kegiatan sehari-hari. Pada hal ini pengguna e-Kinerja menunjukan sikap optimis, di mana pengguna percaya bahwa dalam menggunakan e-Kinerja dapat menghemat waktu dan mempermudah dalam melaporkan kegiatan yang telah diselesaikan pada setiap harinya. Hasil penelitian sebelumnya menunjukan optimis tidak signifikan pada persepsi kemudahan (Martens, Roll, \& Elliott, 2017).

Persepsi kemudahan (Perceived Ease of Use) pengguna berpengaruh signifikan terhadap persepsi kegunaan (Perceived Usefulness) pada E-Kinerja (PEOU $\rightarrow$ PU) pada H8. Faktor yang mempengaruhi persepsi kemudahan pengguna e-Kinerja adalah Ease of learning, Easy to use, Ease of Remembering dan Flexible. Ease of learning didefinisikan sejauh mana sistem mudah dipelajari dan dipahami, Easy to use didefinisikan tingkat kemudahan sistem untuk dipergunakan dalam sehari-hari, Ease of Remembering diartikan sebagai kemudahan dalam menggunakan sistem untuk diingat pada saat dipergunakan dan tidak membuat pengguna bingung, dan Flexible didefinisikan sebagaimana sistem dapat dipergunakan dengan mudah pada lingkungan kerja. Dapat dilihat pada pengguna yang sangat cepat dalam implementasi dari aplikasi e-Kinerja dalam jangka waktu beberapa bulan. e-Kinerja sangat mudah untuk dipahami oleh pengguna karena tampilan aplikasi e-Kinerja sangat simpel dan jelas, sehingga mudah untuk diingat tata cara saat menggunakan e-Kinerja. e-Kinerja juga dapat digunakan pada lingkungan Polresta Sidoarjo dan juga bisa digunakan diluar lingkungan Polresta Sidoarjo sehingga sangat mudah digunakan dimana saja oleh anggota Polresta Sidoarjo. Hasil penelitian sebelumnya menunjukan signifikan antara persepsi kemudahan dan persepsi kegunaan (Martens, Roll, \& Elliott, 2017; Aisyah, Nugroho, \& Sagoro, 2014). 
Penelitian sebelumnya Kim dan Chiu (2019) menjukan hasil yang signifikan antara persepsi kegunaan dan niat penggunaan. Persepsi kegunaan (Perceived Usefulness) berpengaruh signifikan pada niat pengguna (Intention to Use) (PU $\rightarrow$ ITU) pada H6. Faktor yang mempengaruhi persepsi kegunaan terhadap niat pengguna adalah Effectiveness, Quality of work, Increase productivity dan Job performance. Effectiveness didefinisikan sejauh mana seseorang dapat merasakan kegunaan dalam menggunakan sistem yang dapat membantu pengguna dalam menyelesaikan perkerjaan. Quality of work dapat didefinisikan pengguna yang merasakan kegunaan sistem dalam membantu meringankan pekerjaan pengguna, sehingga kualitas pengguna dalam bekerja dapat maksimal. Increase productivity didefinisikan sejauh mana pengguna merasakan kegunaan dalam menggunakan sustu sistem yang dapat membantu pengguna untuk menyelesaikan pekerjaan yang lebih banyak daripada sebelumnya tidak menggunakan teknologi. Job performance didefinisikan sejauh mana kinerja pengguna pada saat menggunakan sistem dapat meningkatkan kinerja dalam menyelesaikan pekerjaan yang ada. Polresta Sidoarjo sangat niat dalam menggunakan aplikasi e-Kinerja karena dengan manfaat yang dirasakan oleh instansi dan pengguna dalam bertugas menimbulkan semangat untuk menggunakan aplikasi eKinerja. Dengan melihat aspek kinerja mereka sebelum dan sesudah menggunakan sangat berbeda sekali, manfaat e-Kinerja sangat tampak sekali dari sisi waktu dalam pelaporan yang sangat efisien sehingga dapat mempersingkat waktu untuk melakukan pekerjaan yang lebih membuat pengguna dapat meningkatkan produktivitas dalam bekerja.

\section{Kesimpulan}

Berdasarkan hasil penelitian dari proses pengujian data dapat beberapa kesimpulan dari tujuan peneitian antara lain: 1) Pertama, dari hasil penelitian ini dapat disimpulkan, bahwa untuk mengetahui penerimaan pengguna E-Kinerja di lingkup polresta meliputi kemudahan (Ease of Use) berpengaruh positif terhadap kepuasan pengguna (User Satisfaction), inovasi (Innovativeness) berpengaruh positif terhadap persepsi kemudahan (Perceived Ease of Use), ketidakamanan (Insecurity) berpengaruh positif terhadap persepsi manfaat (Perceived Usefulness), niat pengguna (Intention to Use) berpengaruh positif terhadap kepuasan pengguna (User Satisfaction), optimis (Optimism) berpengaruh positif terhadap persepsi kemudahan (Perceived Ease of Use), persepsi kemudahan berpengaruh positif terhadap persepsi manfaat (Perceived Usefulness) dan persepsi menfaat berpengaruh positif terhadap niat pengguna (Intention to Use); 2) Kedua, faktor-faktor yang mempengaruhi penerimaan pengguna terhadap aplikasi e-Kinerja yaitu kemudahan (Ease of Use), inovasi (Innovativeness), ketidakamanan (Insecurity), niat pengguna (Intention to Use), optimis (Optimism), persepsi kemudahan (perceived ease of use) dan persepsi kegunaan (perceived usefulness).

Berdasarkan dari hasil penelitian dan batasan-batasan masalah maka penelitian selanjutnya disarankan untuk menambahkan variabel modoresi umur dan jenis kelamin terhadap empat variabel TRAM yaitu optimism, innovativeness, discomfort dan insecurity untuk mengetahui seberapa besar pengaruh terhadap perceived usefulness dan perceived ease of use.

\section{Referensi}

Aditya, R., \& Wardhana, A. (2016). Pengaruh Perceived Usefulness dan Perceived Ease of Use terhadap Behavioral Intention dengan Pendekatan Technology Acceptance Model (TAM) pada Pengguna Instant Messaging Line di Indonesia. Jurnal Siasat Bisnis, 20(1), 24-32.

Aisyah, M. N., Nugroho, M. A., \& Sagoro, E. M. (2014). Pengaruh Technology Readiness Terhadap Penerimaan Teknologi Komputer pada UMKM di Yogyakarta. Jurnal Economia, 10(2), 105-119.

BAŞGÖZE, P. (2015). Integration of Technology Readiness (Tr) into the Technology Acceptance Model (TAM) for M-Shopping. International Journal of Scientific Research and Innovative Technology, 2(3), 2635.

Chen, M.-F., \& Lin, N.-P. (2018). Incorporation of health consciousness into the technology readiness and acceptance model to predict app download and usage intentions. Internet Research, 28(2), 351373.

Dalimunthe, N., \& Ismiati, C. (2016). Analisis Tingkat Kepuasan Pengguna Online Public Access Catalog (OPAC) dengan Metode EUCS (Studi Kasus: Perpustakaan UIN SUSKA Riau). Jurnal Rekayasa dan Manajemen Sistem Informasi, 2(1), 71-75. 
Damayanti, A. S., Mursityo, Y. T., \& Herlambang, A. D. (2018). Evaluasi Kepuasan Pengguna Aplikasi Tapp Market Menggunakan Metode EUCS (End User Computing Satisfaction). Jurnal Pengembangan Teknologi Informasi dan Ilmu Komputer, 2(11), 4833-4839.

Davis, F. D. (1989). Perceived Usefulness, Perceived Ease of Use, and User Acceptance of Information Technology. MIS Quarterly, 13(3), 319-340.

Doll, W. J., \& Torkzadeh, G. (1988). The Measurement of End-User Computing Satisfaction. MIS Quarterly, 12(2), 259-274.

Escrig-Tena, A. B., Segarra-Ciprés, M., García-Juan, B., \& Beltrán-Martín, I. (2018). The impact of hard and soft quality management and proactive behaviour in determining innovation performance. International Journal of Production Economics, 200, 1-14.

Hallikainen, H., \& Laukkanen, T. (2016). How Technology Readiness Explains Acceptance and Satisfaction of Digital Services in B2B Healthcare Sector? Pasific Asia Conference on Information Systems 2016 (PACIS 2016). Chiayi: AISeL.

Humbani, M., \& Wiese, M. (2018). A Cashless Society for All: Determining Consumers' Readiness to Adopt Mobile Payment Services. Journal of African Business, 19(3), 409-429.

Kim, T., \& Chiu, W. (2019). Consumer acceptance of sports wearable technology: the role of technology readiness. International Journal of Sports Marketing and Sponsorship, 20(1), 109-126.

Larasati, N., Widyawan, \& Santosa, P. I. (2017). Technology Readiness and Technology Acceptance Model in New Technology Implementation Process in Low Technology SMEs. International Journal of Innovation, Management and Technology, 8(2), 113-117.

Lin, C.-H., Shih, H.-Y., \& Sher, P. J. (2007). Integrating Technology Readiness into Technology Acceptance: The TRAM Model. Psychology \& Marketing, 24(7), 641-657.

Loanata, T., \& Tileng, K. G. (2016). Pengaruh Trust dan Perceived Risk pada Intention To Use Menggunakan Technology Acceptance Model (Studi Kasus Pada Situs E-Commerce Traveloka). Juisi (Jurnal Informatika dan Sistem Informasi), 2(1), 64-73.

Lubis, F. A., \& Mirzanti, I. R. (2016). The Effects of Technology Readiness and Technology Acceptance Toward Citizens' Participation in Bandung Smart City Project. Journal of Business and Management, 5(2), 277-283.

Martens, M., Roll, O., \& Elliott, R. (2017). Testing the Technology Readiness and Acceptance Model for Mobile Payments Across Germany and South Africa. International Journal of Innovation and Technology Management, 14(06).

Noprianto, R. (2016). Studi Literatur Pengintegrasian Dua Metode Kesiapan dan Penerimaan Pengguna Terhadap Teknologi Informasi dan Komunikasi. Seminar Nasional Teknologi Informasi dan Komunikasi 2016 (SENTIKA 2016) (pp. 154-161). Yogyakarta: Universitas Atma Jaya Yogyakarta.

Panday, R., Wibowo, A., \& Mardiah, S. (2019). Analisis Technology Readiness Acceptance Penggunaan Komputer dan Teknologi Informasi Pada Manajemen Proyek Kontraktor. Jurnal Ilmiah Manajemen Ubhara, 6(1), 33-44.

Parasuraman, A. (2000). Technology Readiness Index (Tri): A Multiple-Item Scale to Measure Readiness to Embrace New Technologies. Journal of Service Research, 2(4), 307-320.

Sari, A. P., \& Syamsuddin, M. A. (2017). Analisis Faktor End-User Computing Satisfaction Terhadap Kepuasan Pengguna: Studi Kasus Kantor Pelayanan Pajak Madya Balikpapan. Jurnal Pajak Indonesia, 1(2), 92-101.

Stefanovic, D., Marjanovic, U., Delić, M., Culibrk, D., \& Lalic, B. (2016). Assessing the success of egovernment systems: An employee perspective. Information \& Management, 53(6), 717-726.

Sutanto, Y. (2015). Analisis Kepuasan Pengguna Website Manajemen Informatika dengan Metode EUCS Berbasis CMS. Informatika, 2(1).

Suzanto, B., \& Sidharta, I. (2015). Pengukuran End-User Computing Satisfaction Atas Penggunaan Sistem Informasi Akademik. Jurnal Ekonomi, Bisnis \& Entrepreneurship, 9(1), 16-28.

Venkatesh, V., Morris, M. G., Davis, G. B., \& Davis, F. D. (2003). User Acceptance of Information Technology: Toward a Unified View. MIS Quarterly, 27(3), 425-478.

Yamin, S., \& Kurniawan, H. (2011). Generasi Baru Mengolah Data Penelitian dengan Partial Least Square Path Modeling. Jakarta: Salemba Infotek. 
Yulianingsih, E. (2016). Analisis Kepuasan Terhadap Penggunaan E-Learning Menggunakan Technology Acceptance Model dan End User Computing Satisfaction. Jurnal Ilmiah Matrik, 18(1), $27-42$. 